\title{
FAKTOR-FAKTOR YANG BERHUBUNGAN DENGAN KEJADIAN DIARE DI KELURAHAN KULIM PUSKESMAS TENAYAN RAYA
}

\author{
Zurni Seprina $^{1}$, Eliza Fitria ${ }^{2}$, Salmiati ${ }^{3}$ \\ ${ }^{1,2,3}$ STIKes Tengku Maharatu, Indonesia \\ Email: zurni.seprina@yahoo.com; fitria_@yahoo.co.id; shalmymia97@gmail.com
}

\begin{abstract}
Diarrhea is the number one cause of death worldwide. Data for 2017 states, nearly 1.7 billion cases of diarrhea occur in children with a mortality rate of around 760.000 in children under five each year WHO (2017). seconds one child dies of diarrhea. The purpose of this study was to determine the factors associated with the occurrence of diarrhea in the community. The design of this study was a quantitative study with a crosssectional approach, with a sample of 50 respondents taken by saturated sampling technique. The results of the study are the relationship of clean water sources ( $p$ value $=$ 0.001 ), family latrines ( $p$ value $=0.012$ ), waste management ( $p$ value $=0.024)$, to the incidence of diarrhea in the community in RT $02 R W 03$ Kulim Village Work Area Puskesmas Tenayan Raya Kota Pekanbaru with the stipulation of $p$ value $(<0.05)$ thus it can be concluded that the source of clean water, family latrines, and waste management are related to the incidence of diarrhea. The suggestion of the results of this study is that the people who become respondents can recognize and understand the clean environment in order to avoid diseases caused by damage to the environment that is less healthy.
\end{abstract}

Keywords : clean water, toilet, waste management, diarrhea

\section{PENDAHULUAN}

Penyakit diare merupakan masalah kesehatan di dunia termasuk Indonesia. Menurut WHO dan UNICEF, terjadi sekitar 2 milyar kasus penyakit diare di seluruh dunia setiap tahun. Semua kematian anak balita karena penyakit diare, $78 \%$ terjadi di wilayah Afrika dan Asia Tenggara (Kemenkes RI, 2011) Penyakit Diare adalah penyakit endemis di Indonesia dan penyakit potensial KLB yang sering disertai dengan kematian. Riset Kesehatan Dasar menunjukkan bahwa Penyakit Diare menjadi penyebab kematian nomor satu pada bayi $(31,4 \%)$ dan pada Balita $(25,2 \%)$, sedangkan pada golongan semua umur merupakan penyebab kematian yang ke empat $(13,2 \%)$ (Ditjen PP \& PL, 2011)

Diare adalah kondisi dimana seseorang buang air besar dengan konsistensi lembek atau cair, bahkan dapat berupa air saja dan frekuensi nya lebih sering (biasanya tiga kali atau lebih) dalam satu hari (Kemenkes RI, 2011).

Penyakit diare dapat diakibatkan dari beberapa faktor. Penelitian Rahman (2016) menunjukkan bahwa faktorfaktor yang berhubungan dengan diare antara lain sanitasi lingkungan, ketersediaan air bersih, hygiene perorangan, sanitasi makanan, ketersediaan jamban, dan perilaku buang 
tinja. Faktor sanitasi lingkungan merupakan faktor yang lebih memengaruhi terjadinya diare.

Berdasarkan Profil Dinkes Pekanbaru tahun 2015 jumlah penderita diare sebanyak 7.051, sedangkan pada tahun 2016 jumlah penderita diare sebanyak 8.877 orang. Data penderita diare di Puskesmas Tenayan Raya pada tahun 2019 sebanyak 241 kasus.

\section{METODE}

Penelitian ini menggunakan desain studi potog lintang (cross-sectional), penelitian ini dilakukan di RT 02 RW 03 kelurahan Kulim wilayah kerja Puskesmas Tenayan Raya Kota Pekanbaru, waktu penelitian dilaksanakan dari bulan Mei sampai dengan Oktober 2019.

Populasi pada penelitian ini adalah seluruh Kepala Keluarga atau ibu rumah tangga yang ada di RT 02 RW 03 Kelurahan Kulim Kecamatan Tenayan Raya Kota Pekanbaru sebanyak 50 orang. Teknik pengambilan sampel dalam penelitian ini adalah Sampling jenuh.

Sampel penelitian ini seluruh Kepala Keluarga atau ibu rumah tangga yang ada di RT 02 RW 03 Kelurahan Kulim Kecamatan Tenayan Raya Kota Pekanbaru sebanyak 50 orang.

Alat ukur dalam penelitian ini yaitu menggunakan kuesioner untuk semua variabel. Analisa data secara univariat dan bivariate. Analisa data univariat menggunakan distribusi frekuensi dan analisa data bivariate menggunakan uji Chi Square.

\section{HASIL DAN PEMBAHASAN}

\section{Analisa Univariat}

Analisa univariat mengemukakan data tentang karakteristik responden, dan dapat dilihat pada tabel dibawah ini:

\section{Tabel 1. Distribusi Karakteristik} Responden

\begin{tabular}{clrr}
\hline No & Variabel & $\begin{array}{r}\text { Frekuensi } \\
(\boldsymbol{f})\end{array}$ & $(\boldsymbol{\%})$ \\
\hline $\mathbf{1}$ & Umur & & \\
& $17-25$ & 13 & 26 \\
& $26-35$ & 29 & 58 \\
& $36-45$ & 8 & 16 \\
\hline & Total & 50 & 100 \\
\hline $\mathbf{2}$ & Jenis & & \\
& Kelamin & & \\
& Laki-laki & 23 & 46 \\
& Perempuan & 27 & 54 \\
\hline & Total & 50 & 100 \\
\hline $\mathbf{3}$ & Pekerjaan & & \\
& Pedagang & 27 & 54 \\
& Buruh & 2 & 4 \\
& PNS & 2 & 4 \\
& Wiraswasta & 14 & 28 \\
& Petani & 5 & 10 \\
\hline & Total & 50 & 100 \\
\hline $\mathbf{4}$ & Pendidikan & & \\
& SD & 7 & 14 \\
& SLTP & 14 & 28 \\
& SLTA & 22 & 44 \\
& Peguruan & 7 & 14 \\
& Tinggi/ & & \\
Akademi & & \\
\hline & Total & 50 & 100 \\
\hline & & &
\end{tabular}

Berdasarkan tabel 1 bahwa dari 50 responden mayoritas berumur 26-35 tahun yaitu 29 orang (58\%) dan 
minoritas berumur 36-45 tahun sebanyak 8 orang $(16 \%)$. Mayoritas responden berjenis kelamin perempuan sebanyak 27 orang (54\%) dan minoritas laki-laki sebanyak 23 (46\%). Mayoritas responden bekerja sebagai pedagang 27 orang (54\%), dan minoritas buruh dan PNS sebanyak 2 orang (4\%). Mayoritas responden berpendidikan terakhir 22 orang SLTA (44\%), dan minoritas SD dan PT sebanyak 7 orang (14\%).

Tabel 2. Distribusi Frekuensi Kualitas Sumber Air Bersih

\begin{tabular}{clcc}
\hline No & $\begin{array}{l}\text { Kualitas } \\
\text { Sumber Air } \\
\text { Bersih }\end{array}$ & $\begin{array}{c}\text { Frekuensi } \\
(\boldsymbol{f})\end{array}$ & $(\mathbf{\%})$ \\
\hline $\mathbf{1}$ & $\begin{array}{l}\text { Memenuhi } \\
\text { Syarat }\end{array}$ & 32 & 64 \\
\hline $\mathbf{2}$ & $\begin{array}{l}\text { Tidak } \\
\text { Memenuhi } \\
\text { Syarat }\end{array}$ & 18 & 36 \\
\hline \multicolumn{2}{c}{ Total } & $\mathbf{5 0}$ & $\mathbf{1 0 0}$ \\
\hline
\end{tabular}

Berdasarkan tabel 2 bahwa mayoritas responden memiliki kualitas sumber air bersih memenuhi syarat sebanyak 32 responden (64\%). Sedangkan minoritas responden memiliki kualitas sumber air bersih tidak memenuhi syarat sebanyak 18 responden (36\%).

\section{Tabel 3. Distribusi Frekuensi Jamban} Sehat

\begin{tabular}{clcc}
\hline No & $\begin{array}{l}\text { Jamban } \\
\text { Sehat }\end{array}$ & $\begin{array}{c}\text { Frekuensi } \\
(\boldsymbol{f})\end{array}$ & $\mathbf{( \% )}$ \\
\hline $\mathbf{1}$ & $\begin{array}{l}\text { Memenuhi } \\
\text { Syarat }\end{array}$ & 38 & 76 \\
\hline $\mathbf{2}$ & $\begin{array}{l}\text { Tidak } \\
\text { Memenuhi } \\
\text { Syarat }\end{array}$ & 12 & 24 \\
\hline \multicolumn{2}{c}{ Total } & $\mathbf{5 0}$ & $\mathbf{1 0 0}$ \\
\hline & & &
\end{tabular}

Berdasarkan tabel 3 bahwa mayoritas responden memiliki jamban sehat memenuhi syarat sebanyak 38 orang (76\%). Sedangkan minoritas responden memiliki jamban sehat tidak memenuhi syarat sebanyak $12(24 \%)$.

\section{Tabel 4. Distribusi Frekuensi Pengelolaan Sampah}

\begin{tabular}{clcc}
\hline No & $\begin{array}{l}\text { Pengelolaan } \\
\text { Sampah }\end{array}$ & $\begin{array}{c}\text { Frekuensi } \\
(\boldsymbol{f})\end{array}$ & $\mathbf{( \% )}$ \\
\hline $\mathbf{1}$ & $\begin{array}{l}\text { Memenuhi } \\
\text { Syarat }\end{array}$ & 38 & 76 \\
\hline $\mathbf{2}$ & $\begin{array}{l}\text { Tidak } \\
\text { Memenuhi } \\
\text { Syarat }\end{array}$ & 12 & 24 \\
\hline \multicolumn{2}{c}{ Total } & $\mathbf{5 0}$ & $\mathbf{1 0 0}$ \\
\hline & & &
\end{tabular}

Berdasarkan tabel 4 bahwa mayoritas responden melakukan cara pengelolaan sampah memenuhi syarat sebanyak 38 orang (76\%). Sedangkan minoritas responden pengelolaan sampah yang tidak memenuhi syarat sebanyak 12 (24\%).

\section{Tabel 5. Distribusi Frekuensi Kejadian}

\begin{tabular}{lccc}
\hline No & $\begin{array}{c}\text { Kejadian } \\
\text { Diare }\end{array}$ & $\begin{array}{c}\text { Frekuensi } \\
(\boldsymbol{f})\end{array}$ & $\mathbf{( \% )}$ \\
\hline $\mathbf{1}$ & Ya & 20 & 40 \\
\hline $\mathbf{2}$ & Tidak & 30 & 60 \\
\hline & Total & $\mathbf{5 0}$ & $\mathbf{1 0 0}$ \\
\hline
\end{tabular}

Berdasarkan tabel 5 bahwa mayoritas Responden dengan kategori mengalami kejadian diare yaitu sebanyak 20 orang (40\%). Sedangkan minoritas responden yang tidak mengalami kejadian Diare sebanyak 30 orang $(60 \%)$. 


\section{Analisa Bivariat}

Tabel 6. Hubungan Kualitas Sumber Air Bersih Terhadap Kejadian Diare

\begin{tabular}{|c|c|c|c|c|c|c|c|c|c|}
\hline \multirow{3}{*}{ No } & \multirow{3}{*}{$\begin{array}{l}\text { Kualitas } \\
\text { Sumber Air } \\
\text { Bersih }\end{array}$} & \multicolumn{4}{|c|}{ Kejadian Diare } & \multirow{2}{*}{\multicolumn{2}{|c|}{ Jumlah }} & \multirow{3}{*}{$\begin{array}{c}p \\
\text { value }\end{array}$} & \multirow{3}{*}{ OR } \\
\hline & & \multicolumn{2}{|r|}{ Ya } & \multicolumn{2}{|c|}{ Tidak } & & & & \\
\hline & & $f$ & $\%$ & $f$ & $\%$ & $\mathbf{N}$ & $\%$ & & \\
\hline 1 & Memenuhi syarat & 7 & 21,9 & 25 & 78,1 & 32 & 100 & & \\
\hline 2 & $\begin{array}{l}\text { Tidak memenuhi } \\
\text { Syarat }\end{array}$ & 13 & 72,2 & 5 & 27,8 & 18 & 100 & 0,001 & $(2.458-$ \\
\hline & Jumlah & 20 & 40,0 & 30 & 60,0 & 50 & 100 & & \\
\hline
\end{tabular}

Berdasarkan tabel 6 bahwa diperoleh hasil dari 32 yang memiliki kualitas sumber air bersih yang memenuhi syarat, yang mengalami kejadian diare yaitu sebanyak 7 (21,9\%), dan yang tidak mengalami kejadian diare sebanyak 25 (78,1\%), sedangkan 18 yang tidak memenuhi syarat yang mengalami kejadian diare sebanyak 13 $(72,2 \%)$, dan yang tidak mengalami kejadian diare sebanyak 5 (27,8\%).

Hasil uji statistik menggunakan uji Chi Square diperoleh $p$ value $=0,001$, dengan demikian $p$ value $\leq \alpha(<0,05)$ sehingga ho ditolak. Maka dapat disimpulkan bahwa, ada hubungan yang signifikan sumber air bersih terhadap kejadian diare, dan diperoleh Nilai $O R$ $($ Odds Ratio $)=9,286(2.458-35.074)$ hal ini menunjukkan bahwa sumber air bersih yang tidak memenuhi syarat mempunyai resiko kejadian diare sebesar 9,2 kali.

\section{Tabel 7. Hubungan Jamban Sehat Terhadap Kejadian Diare}

\begin{tabular}{|c|c|c|c|c|c|c|c|c|c|}
\hline \multirow{3}{*}{ No. } & \multirow{3}{*}{ Jamban sehat } & \multicolumn{4}{|c|}{ Kejadian Diare } & \multirow{2}{*}{\multicolumn{2}{|c|}{ Jumlah }} & \multirow{3}{*}{$\begin{array}{c}p \\
\text { value }\end{array}$} & \multirow{3}{*}{$\mathbf{O R}$} \\
\hline & & \multicolumn{2}{|c|}{ Ya } & \multicolumn{2}{|c|}{ Tidak } & & & & \\
\hline & & $f$ & $\%$ & $f$ & $\%$ & $\mathbf{N}$ & $\%$ & & \\
\hline 1 & Memenuhi syarat & 11 & 28,9 & 27 & 71,1 & 38 & 100 & & \\
\hline 2 & $\begin{array}{l}\text { Tidak memenuhi } \\
\text { syarat }\end{array}$ & 9 & 75,0 & 3 & 25,0 & 12 & 100 & 0,012 & $\begin{array}{c}7,364 \\
(1.671-32.440)\end{array}$ \\
\hline & Jumlah & 20 & 40,0 & 30 & 60.0 & 50 & 100 & & \\
\hline
\end{tabular}

Berdasarkan tabel 7 bahwa diperoleh hasil dari 38 yang memiliki jamban sehat yang memenuhi syarat mengalami kejadian diare yaitu sebanyak 11 $(28,9 \%)$, dan yang tidak mengalami kejadian diare sebanyak 27 (71.1\%), dari 12 yang tidak memenuhi syarat yang mengalami kejadian diare sebanyak 9 $(75,0 \%)$, dan yang tidak mengalami kejadian diare sebanyak $3(25,0 \%)$.

Hasil uji statistik menggunakan uji Chi Square diperoleh $p$ value $=0,012$, dengan demikian $p$ value $\leq \alpha(<0,05)$ sehingga ho ditolak. Maka dapat 
disimpulkan bahwa, ada hubungan yang signifikan jamban keluarga terhadap kejadian diare di RT 02 RW 03 Kelurahan Kulim Kecamatan Tenayan Raya Kota Pekanbaru. Nilai OR (Odds
Ratio $)=7,364(1.671-32.440)$ hal ini menunjukkan bahwa jamban keluarga yang tidak memenuhi syarat mempunyai resiko kejadian diare sebesar 7,3 kali.

Tabel 8. Hubungan Pengelolaan Sampah Terhadap Kejadian

\begin{tabular}{|c|c|c|c|c|c|c|c|c|c|}
\hline \multirow{3}{*}{ No } & \multirow{3}{*}{$\begin{array}{c}\text { Pengelolaan } \\
\text { Sampah }\end{array}$} & \multicolumn{4}{|c|}{ Kejadian Diare } & \multirow{2}{*}{\multicolumn{2}{|c|}{ Jumlah }} & \multirow{3}{*}{$\begin{array}{c}p \\
\text { value }\end{array}$} & \multirow{3}{*}{ OR } \\
\hline & & \multicolumn{2}{|c|}{ Ya } & \multicolumn{2}{|c|}{ Tidak } & & & & \\
\hline & & $f$ & $\%$ & $f$ & $\%$ & $\mathbf{N}$ & $\%$ & & \\
\hline 1 & Memenuhi syarat & 6 & 23,1 & 20 & 76,9 & 26 & 100 & \multirow{3}{*}{0,024} & \multirow{3}{*}{$\begin{array}{c}4,667 \\
(1.376-15.823)\end{array}$} \\
\hline 2 & $\begin{array}{l}\text { Tidak memenuhi } \\
\text { syarat }\end{array}$ & 14 & 58,3 & 10 & 41,7 & 24 & 100 & & \\
\hline & Jumlah & 20 & 40.0 & 30 & 60.0 & 50 & 100 & & \\
\hline
\end{tabular}

Berdasarkan tabel 8 bahwa diperoleh hasil dari 26 yang melakukan pengelolaan sampahnya yang memenuhi syarat yang mengalami kejadian diare yaitu sebanyak $6(23,1 \%)$, dan yang tidak mengalami kejadian diare 20 (76,9\%), dari 24 tidak memenuhi syarat yang mengalami kejadian diare sebanyak $14(58,3 \%)$, dan yang tidak mengalami sebanyak $10(41,7)$.

Hasil uji statistik menggunakan uji Chi Square diperoleh $p$ value $=0,024$, dengan demikian $p$ value $\leq \alpha(<0,05)$ sehingga ho ditolak. Maka dapat disimpulkan bahwa, ada hubungan yang signifikan pengelolaan sampah terhadap kejadian diare di RT 02 RW 03 Kelurahan Kulim Kecamatan Tenayan Raya Kota Pekanbaru. Nilai OR (Odds Ratio $)=4,667(1.376-15.823)$ hal ini menunjukkan bahwa pengelolaan sampah yang tidak memenuhi syarat beresiko kejadian diare 4,6 kali.
Pembahasan

Hubungan Kualitas Sumber Air Bersih Terhadap Kejadian Diare

Hasil penelitian hubungan sumber air bersih terhadap kejadian diare pada anak di RT 02 RW 03 Kelurahan Kulim Kecamatan Tenayan Raya Kota Pekanbaru, bahwa diperoleh hasil dari 32 yang memiliki kualitas sumber air bersih yang memenuhi syarat, yang mengalami kejadian diare yaitu sebanyak 7 (21,9\%), dan yang tidak mengalami kejadian diare sebanyak 25 $(78,1 \%)$, sedangkan 18 yang tidak memenuhi syarat yang mengalami kejadian diare sebanyak 13 (72,2\%), dan yang tidak mengalami kejadian diare sebanyak $5(27,8 \%)$.

Hasil uji statistik menggunakan uji Chi Square diperoleh $p$ value $=0,001$, dengan demikian $p$ value $\leq \alpha(<0,05)$ sehingga ho ditolak. Maka dapat disimpulkan bahwa, ada hubungan yang signifikan sumber air bersih terhadap 
kejadian diare, dan diperoleh Nilai $O R$ $($ Odds Ratio $)=9,286(2.458-35.074)$ hal ini menunjukkan bahwa sumber air bersih yang tidak memenuhi syarat mempunyai resiko kejadian diare sebesar 9,2 kali.

Sumber air bersih masyarakat RT 02 RW 03 Kelurahan Kulim Kecamatan Tenayan Raya Kota Pekanbaru dengan jarak septik tank kurang dari 10 meter dan air minum menggunakan air galon isi ulang,

Air sebagai salah satu media transmisi penyakit, karena itu perlu untuk diawasi kualitasnya agar nilainya tetap sesuai standar baku mutu kesehatan agar penularan penyakit melalu air dapat dicegah dan dihilangkan. Kebutuhan masyarakat akan air bersih menegaskan bahwa pegawasan air harus dilakukan dengan teliti dan teratur serta perlunya dilakukan tindakan pengawasan serta pencegahan pencemaran sumber-sumber air bersih masyarakat.

Penelitian ini sejalan dengan penelitian Suci, Otniel, dan Asima, (2017), ada hubungan yang bermakna sumber air dengan kejadian diare Di Puskesmas Perawatan Ngkeran Kabupaten Aceh Tenggara. Berdasarkan hasil uji chi square diperoleh $p$ value $=$ ,000 artinya ada hubungan antara sumber air dengan kejadian diare pada balita.

\section{Hubungan Jamban Sehat Terhadap Kejadian Diare}

Hasil penelitian hubungan jamban sehat dan kejadian diare pada masyarakat di RT 02 RW 03 Kelurahan Kulim Kecamatan Tenayan Raya Kota Pekanbaru, bahwa diperoleh hasil dari 38 yang memiliki jamban sehat yang memnuhi syarat yang mengalami kejadian diare yaitu sebanyak 11 $(28,9 \%)$, dan yang tidak mengalami kejadian diare sebanyak 27 (71.1\%), dari 12 yang tidak memenuhi syarat yang mengalami kejadian diare sebanyak 9 $(75,0 \%)$, dan yang tidak mengalami kejadian diare sebanyak 3 (25,0\%).

Hasil uji statistik menggunakan uji Chi Square diperoleh $p$ value $=0,012$, dengan demikian $p$ value $\leq \alpha(<0,05)$ sehingga ho ditolak. Maka dapat disimpulkan bahwa, ada hubungan yang signifikan jamban sehat terhadap kejadian diare di RT 02 RW 03 Kelurahan Kulim Kecamatan Tenayan Raya Kota Pekanbaru. Nilai OR (Odds Ratio $)=7,364(1.671-32.440)$ hal ini menunjukkan bahwa jamban keluarga yang tidak memenuhi syarat mempunyai resiko kejadian diare sebesar 7,3 kali.

Jamban yang dimiliki oleh masyarakat di RT 02 RW 03 Kelurahan Kulim Kecamatan Tenayan Raya Kota Pekanbaru masih banyak memakai jamban cubluk dan belum permanen karena dinding jamban hanya terbuat 
dari terpal, dan lantai jamban hanya terbuat papan.

Terdapat dua macam bentuk bangunan bawah jamban, yaitu: Tangki septik, adalah suatu bak kedap air yang berfungsi sebagai penampungan limbah kotoran manusia (tinja dan urine). Bagian padat dari kotoran manusia akan tertinggal dalam tangki septik, sedangkan bagian cairnya akan keluar dari tangki septik dan diresapkan melalui bidang/sumur resapan. Jika tidak memungkinkan dibuat resapan maka dibuat suatu filter untuk mengelola cairan tersebut. Cubluk, merupakan lubang galian yang akan menampung limbah padat dan cair dari jamban yang masuk setiap harinya dan akan meresapkan cairan limbah tersebut kedalam tanah dengan tidak mencemari air tanah, sedangkan bagian padat dari limbah tersebut akan diuraikan secara biologis. Bentuk cubluk dapat dibuat bundar atau segi empat, dindingnya harus aman dari longsoran, jika diperlukan dinding cubluk diperkuat dengan pasangan bata, penguat kayu, dan sebagainya (Permenkes, 2014)

Penelitian ini sejalan dengan Suci, dkk (2017) ada hubungan jamban dengan kejadian diare pada anak balita di Puskesmas Perawatan Ngkeran Kabupaten Aceh Tenggara. Penelitian Melviana, Dharma, Naria, dan et al. (2014) menunjukkan adanya hubungan antara sanitasi jamban khususnya penggunaan jamban dan air dengan kejadian diare pada anak balita di Kelurahan Terjun.

\section{Hubungan Pengelolaan Sampah Terhadap Kejadian Diare}

Hasil penelitian hubungan pengelolaan sampah rumahtangga dan kejadian diare responden di RT 02 RW 03 Kelurahan Kulim Kecamatan Tenayan Raya Kota Pekanbaru, bahwa diperoleh hasil dari 26 yang melakukan pengelolaan sampahnya yang memenuhi syarat yang mengalami kejadian diare yaitu sebanyak $6(23,1 \%)$, dan yang tidak mengalami kejadian diare 20 (76,9\%), dari 24 tidak memenuhi syarat yang mengalami kejadian diare sebanyak $14(58,3 \%)$, dan yang tidak mengalami sebanyak $10(41,7)$.

Hasil uji statistik menggunakan uji Chi Square diperoleh $p$ value $=0,024$, dengan demikian $p$ value $\leq \alpha(<0,05)$ sehingga ho ditolak. Maka dapat disimpulkan bahwa, ada hubungan yang signifikan pengelolaan sampah rumah tangga terhadap kejadian diare di RT 02 RW 03 Kelurahan Kulim Kecamatan Tenayan Raya Kota Pekanbaru. Nilai OR $($ Odds Ratio $)=4,667$ (1.376-15.823) hal ini menunjukkan bahwa pengelolaan sampah yang tidak memenuhi syarat beresiko kejadian diare 4,6 kali.

Perilaku pengamanan sampah rumah tangga sebagaimana dimaksud dalam Pasal 3 ayat (2) huruf d diwujudkan 
melalui kegiatan paling sedikit terdiri atas: Membudayakan perilaku memilah sampah rumah tangga sesuai dengan jenisnya dan membuang sampah rumah tangga di luar rumah secara rutin; Melakukan pengurangan (reduce), penggunaan kembali (reuse), dan pengolahan kembali (recycle) dan Menyediakan dan memelihara sarana pembuangan sampah rumah tangga di luar rumah (Permenkes, 2014)

Penelitian ini sejalan dengan Syahrizal (2016) bahwa ada hubungan antara penanganan sampah dengan kejadian diare pada balita di wilayah kerja Puskesmas Ingin Jaya Kabupaten Aceh Besar. Penelitian Lidiawati (2016) diketahui bahwa ada hubungan yang bermakna antara penyediaan air bersih, penggunaan jamban, dan pembungan sampah dengan angka kejadian diare pada balita. Penelitian Langit (2016) diketahui bahwa ada hubungan yang bermakna antara penyediaan air bersih, penggunaan jamban, dan pembungan sampah dengan angka kejadian diare pada balita.

Pengelolaan sampah pada masyarakat di RT 02 RW 03 Kelurahan Kulim Kecamatan Tenayan Raya Kota Pekanbaru masih banyak ditemukan masyarakat sampah nya tidak dipisah pisah menurut jenisnya dan pengelolaan sampahnya banyak yang dibuang disekitar rumah dan dibakar.

\section{KESIMPULAN DAN SARAN}

\section{Kesimpulan}

1. Distribusi kejadian diare mayoritas dengan kategori dengan tidak kejadian diare yaitu 30 orang $(60 \%)$.

2. Ada hubungan yang signifikan sumber air bersih terhadap kejadian diare di RT 02 RW 03 Kelurahan Kulim Kecamatan Tenayan Raya Kota Pekanbaru dengan nilai $p$ value $=0.001$

3. Ada hubungan yang signifikan jamban keluarga terhadap kejadian diare di RT 02 RW 03 Kelurahan Kulim Kecamatan Tenayan Raya Kota Pekanbaru dengan nilai $p$ value $=0.012$

4. Ada hubungan yang signifikan pengelolaan sampah terhadap kejadian diare di RT 02 RW 03 Kelurahan Kulim Kecamatan Tenayan Raya Kota Pekanbaru dengan nilai $p$ value $=0.024$.

\section{Saran}

\section{Bagi Puskesmas Tenayan Raya}

Diharapkan dapat Menjadi data informasi sebagai dasar dalam membuat program di Puskesmas Tenayan Raya, dan menjadi acuan bagi Puskesmas untuk melakukan aktivitas promotof, preventif, kuratif dan rehabilitatif terkait Diare. 


\section{Bagi Masyarakat}

Diharapkan agar masyarakat dapat mengenali dan memahami kondisi lingkungan yang bersih agar terhindar dari penyakit-penyakit akibat kerusakan lingkungan yang kurang sehat.

\section{Bagi Dinas Kesehatan Kota Pekanbaru}

Diharapkan agar menjadi data base yang memiliki manfaat lebih bagi dinas kesehatan dalam melakukan upaya pencegahan penyakit yang berbasis lingkungan khususnya pada diare

\section{Bagi Peneliti Selanjutnya}

Diharapkan dapat menambah wawasan bagi peneliti lainnya sebagai acuan untuk penelitian lebih lanjut mengenai informasi bagi peneliti lain yang peduli terhadap kondisi lingkungan dan kesehatan yang berkaitan dengan penyakit diare secara khususnya.

\section{Bagi STIKes Tengku Maharatu}

Diharapkan dapat informasi bagi seluruh Civitas Akademika STIKes Tengku Maharatu.

\section{DAFTAR PUSTAKA}

Ditjen PP \& PL, K. R. (2011). Profil Kesehatan Indonesia Tahun 2011. In Kementrian Kesehatan Republik Indonesia.

Kemenkes RI. (2011). Situasi diare di Indonesia. Jurnal buletin jendela data \& informasi kesehatan.

Lidiawati, M. (2016). Hubungan sanitasi lingkungan dengan angka kejadian diare pada balita di wilayah kerja Puskesmas Meuraxa tahun 2016. Jurnal serambi saintia.

Lintang, L. S. (2016). Hubungan kondisi sanitasi dasar rumah dengan kejadian diare pada balita di wilayah kerja puskesmas rembang 2. Jurnal kesehatan masyarakat (e-journal).

Melviana, M., Dharma, S., Naria, E., \& et al. (2014). Hubungan sanitasi jamban dan air bersih dengan kejadian diare pada balita di Kelurahan Terjun Kecamatan Medan Marelan Kota Medan tahun 2014. Fakultas kesehatan masyarakat, universitas sumatera utara.

Permenkes. (2014). Peraturan menteri kesehatan republik indonesia nomor 3 tahun 2014 tentang sanitasi total berbasis masyarakat dengan. Kesehatan. https://doi.org/10.1016/j.cell.2009 .01 .043

Rahman, H. F. (2016). Faktor-faktor yang berhubungan dengan kejadian diare di desa solor kecamatan cermee bondowoso. Teknologi dan industri.

Suci, R., Otniel, K., \& Asima, S. (2017). Faktor-faktor yang berhubungan dengan kejadian diare di Puskesmas Perawatan Ngkeran Kabupaten Aceh Tenggara pada tahun 2017. Jurnal Ilmiah Simantek, 1(3). Retrieved from http://sciencemakarioz.org/ jurnal/index.php/simantek/article/ view/156/155

Syahrizal. (2016). Hubungan penanganan sampah dengan kejadian diare pada balita di Wilayah Kerja Puskesmas Ingin Jaya Kabupaten Aceh Besar. Jurnal Ilmiah Kesehatan Nasuwakes, 9(1), 69-75. 